\title{
Technical and Vocational Education in Malaysia: Policy, Leadership, and Professional Growth on Malaysia Women
}

\author{
Nor Lisa Sulaiman ${ }^{1}$, Kahirol Mohd Salleh ${ }^{1}$, Mimi Mohaffyza Mohamad ${ }^{1} \&$ Lai Chee Sern ${ }^{1}$ \\ ${ }^{1}$ Universiti Tun Hussein Onn Malaysia, Parit Raja, Malaysia \\ Correspondence: Nor Lisa Sulaiman, Faculty of Technical and Vocational Education, Universiti Tun Hussein \\ Onn Malaysia, 86400 Parit Raja, Malaysia. Tel: 607-456-4191. E-mail: norlisa@uthm.edu.my
}

\author{
Received: April 30, 2015 Accepted: June 28, 2015 Online Published: August 18, 2015 \\ doi:10.5539/ass.v11n24p153 URL: http://dx.doi.org/10.5539/ass.v11n24p153
}

\begin{abstract}
Technical and Vocational Education (TVE) is facing new challenges in an increasingly competitive global context. The continuing under representation of women in engineering fields at semi-skilled and high-skilled levels is receiving renewed attention. This paper explores women as part of special population in Malaysia who desire to be placed as equal to men in Malaysian context. Policy, leadership, and professional growth are discussed comprehensively to support Malaysian females' involvement in engineering disciplines, one of Technical and Vocational Education (TVE) programs in Malaysia. This paper also explores issues and challenges facing by Malaysian women in order to be recognized by the sub-ordinates, peers, leaders and society within male-dominated professions and environment.
\end{abstract}

Keywords: technical and vocational education, gender issues, policy, leadership, professional growth

\section{Introduction}

Malaysia is seeking to improve the quality of life in its society through developing their workforce to compete in the global economy. Advances and improvements have been made through Malaysian education and industry for "greater economic and social development" (Kefela, 2010). Female participation is emphasized as part of the national agenda providing opportunities for women to increase their positions in Malaysian society and to contribute their knowledge and skills towards the national growth and development (Malaysia Government, 2006). This initiative was implemented to ensure that women have equal opportunities to provide contributions to the economic development of Malaysia.

With rapid changes in technology, engineering is one of the preferred disciplines in Malaysia. Engineering positions are increasing in industrial organizations in Malaysia (Ismail, 2003). Malaysian female students are motivated to pursue their education at universities as chances to be employed in engineering professionals and technical fields increase. Malaysian government provides opportunities for women to acquire advanced skills to be competitive in the engineering field (Malaysia Government, 2006). According to Ismail (2003), people in Malaysia still perceive engineering as a male-dominated profession and women are stereotyped as unskilled and incompetent as engineers. She stated that "Malaysian female engineers accounted for less than 10 percent of the total professional workforce despite the encouraging number of Malaysian females enrolling in the field of engineering, locally and abroad". Due to that the inequity of hiring practices in the engineering field, high percentages of Malaysian females graduating from the engineering field become teachers (Ismail, 2003). Even though the women lag in numbers when considering the total number of people employed in the engineering arena, issues surrounding the area of gender equality within the engineering field are often debated including in educational setting (Rodgers \& Boyer, 2006).

This paper explores women as part of a special population in Malaysia who desire to be placed as equal to men in Malaysian society. Policy, leadership, and professional growth will be incorporated to support Malaysian females' involvement in engineering disciplines, one of Technical and Vocational Education (TVE) programs in Malaysia.

\section{Background}

Malaysian women comprise almost half of the Malaysian population (Haque \& Chandran, 2004). In general, women in Malaysia are seen as being soft, gentle, and compassionate while preserving the traditional values and 
culture at home and in the community (Noor, 1999). Traditionally, the Malaysian women are perceived as mothers, housewives, caretakers, and caregivers. Malaysian women are responsible to take care of children, complete house chores, take care of laundry, cook meals for the family and ensure family needs are met. The Malaysian women's life is also impacted by different religions, beliefs, values, and cultures within the Malaysian society (Noor, 1999).

Malaysian women's involvement and support of engineering started prior to Malaysian independence. Ahmad (1998) claimed 43.4 percent of the workforce was comprised of Malaysian women in engineering especially manufacturing field as semi-skilled assembly workers. This represents one of the highest rates of women in engineering among the Asian and Pacific industrialized countries. Malaysian female students are entering the engineering field in higher numbers as the number of engineering programs increases in public polytechnics and universities in Malaysia. The first public polytechnic in Malaysia was established in 1969, where it trained secondary school graduates to become semi-skilled professionals such as technicians and mechanics for government and the industrial sectors in Malaysia (Mustapha \& Abdullah, 2001). Although polytechnics programs were offered at a certificate level, most of Malaysian polytechnic graduates pursued their degree level at Malaysian public universities. Female students in engineering were estimated at 51.3 percent of the total enrollment in the Malaysian universities in 2000 (Malaysia Government, 2003). Female participation in engineering increased when Malaysia sought to drive its economy from agriculture into industrial sectors (Azman \& Ahmad, 2006). Since then, universities in Malaysia offer various new engineering programs to meet the requirement of job demands in engineering field. These new changes have had a positive impact on Malaysian society where the participations and contributions of Malaysian women in engineering are significant.

Malaysia experienced a bad economic downturn reflected by the global economic crisis of the late 1990's (Ahmad, 1998) where Malaysian women were also affected and oppressed at those particular years. Although gender bias and discrimination were acknowledged publically, most Malaysian women workers were the first to lose jobs especially in the engineering sectors. This showed that the industries preferred male contribution and segregated engineering jobs according to gender (Ahmad, 1998) and this gender-specific impact may imperil future development in Malaysia. Nevertheless, Malaysian government is aware of these critical issues. Hence, continuous initiatives have been made to improve education system as well as work opportunities for Malaysian women through the establishments of national developmental policies, plans, and objectives. The Malaysian government seeks to reinforce the role and status of women in Malaysian socioeconomics, including education (Azman \& Ahmad, 2006) to help and encourage Malaysian women in sharing their responsibility which also shall increase their contributions to the Malaysian economic development (Ministry of Women, Family and Community Development, 2011). Accordingly, these endless efforts and initiatives can promote women's right and raises public perception on the importance of the role of women in Malaysian.

\section{Technical and Vocational Education}

Technical and Vocational Education (TVE), Vocational Education, Career and Technical Education (CTE), Workforce Education; might sound like different terms but they all share similar objectives. UNESCO-UNEVOC (2010), defined TVE as "the acquisition of knowledge and skills for the world of work". The name has been change over time to shed the stigmatism associated with "Vo Tech" in all its names and to promote TVE as a first class educational system. The stigma is generally global. In China, for example, the culture perceives TVE to be a platform for students who are not able to excel in academic performance. Because of these perceptions Chinese parents prefer their children to get their education at schools and universities which are not vocationally oriented (Velde, 2009).

In Malaysia, students who are not accepted at academic schools and universities can pursue their studies at technical and vocational institutions not as a first choice, but a last result leading to perceptions of failure. Today, the negative perceptions toward TVET have gradually changed where the Malaysian government is making an effort to re-brand and improve TVE programs to reverse the negative stigma and be accepted by the society as vital for driving economic development and individual achievement (Mustapha \& Abdullah, 2001). For example, engineering education is recognized as part of TVE (Haas, 1999). Also, the Malaysian government has provide equitable and transparent TVET support to all educational institutions which allow students from various levels of academic performances to choose TVE for their career pathways (Ministry of Education Malaysia, 2013). Although those initiatives play a significant role in building awareness of the importance of TVET among Malaysian, yet, there are many aspects that need to be highlighted to ensure the nation can deeply understand the specific role of TVET in improving national economic development and social inclusion.

Dennis and Hudson (2007) stated that in the U.S., TVE has been designed to equip students to become high 
skilled workers to directly support the economic growth of the country. TVE programs in the U.S. are offered at certificate and diploma programs, especially at community colleges. Therefore, because it is not prestigious to go through these programs, TVE programs in the U.S. are not viewed with the preference that degree programs are seen through; except perhaps by individuals who are from families of lower socio-economic status.

Regardless of negative perceptions of TVE in some countries, Germany and other European countries have different perspectives on TVE. TVE programs are seen as a primary factor in the human resource development and a main contributor to European economic success (Wu, 2003). European countries were built on the principles of lifelong learning and occupational profiling, which aligned with the development of TVE systems (Wu, 2003). Historically, industries facilitate supportively European national reforms, as the industries have been good collaborators with the government since the very beginning of TVE systems in many European countries (Wu, 2003).

According to Dewey, Montrosse, Schroter, Sullins, and Mattox (2008), the TVE system has been changing rapidly since its presence in education based on work related issues with business and industry. There are also students who give credit to the TVE institutions for offering programs which are in convenient and accessible places and support their academic success of obtaining knowledge and skills required by the industries (O'Gara, Mechur, \& Hughes, 2009). In other words, TVE graduates have more opportunities in getting high-skilled jobs compared to others with lower levels of technical and vocational skills attainment.

\section{Issues on Female Students in Engineering Programs}

Female students tend to choose engineering programs because of the perceived job opportunities upon completion of their studies. Engineering is a viable choice in today's market (Shivy \& Sullivan, 2005). Moreover, family influence female students to pursue their studies in engineering field (Anderson \& Gilbride, 2007). Even though Malaysian female students' enrollment in engineering programs is equal with or greater than male students, the female students have different motivation, different attitude, and different responses in regards to what they learn about engineering (Jelas \& Dahan, 2010). Holvikivi (2007) commented that "engineering education may be a particularly difficult multidisciplinary field because of the differences in epistemological views of learning sciences, and engineering". Although female students' academic achievement in engineering is better compared to male students, active participation continues to be a concern as female students claim that teacher pays more attention to opposite gender (She, 2000). If teacher continues to treat students based on gender-based differences, it will slowly create a hostile learning environment for the female students. Above all, female students will likely prefer non-engineering to create their own future career path.

There is also a common belief among teachers who claim engineering is not a female's job which can "damage the self-esteem and motivation of female students" (Erden, 2009). However, Subrahmanian (2005) claimed "equality of treatment as well as equality of opportunity" between male and female students is important to overcome the differences between their learning outcomes. In education, equality "refers to a situation in which students receive the same quality of teaching and enjoy the same type of school facilities, textbooks, and teaching material" (Magno \& Silova, 2007). Therefore, the gender-specific impact in education should be avoided for students to experience deep learning and enjoy what they learn in class.

Gender gap and gender preference are also factors that impact female students to choose engineering as their career path. Malaysian female students comprise " 12 percent in mechanical engineering, 22 percent in electrical engineering, and 48 percent in civil engineering programs of total enrollment in secondary technical schools in Malaysia" (Malaysia Government, 2003). Malaysian female students prefer to enroll non-engineering programs such as hospitality, technology, business programs compared to engineering (Malaysia Government, 2003). Recently, the number of Malaysian female students in engineering has increased, yet they did not choose engineer as their life profession due to pressure from home and work (Peramayah, 2012). Therefore, Malaysian female students should have equal rights and opportunities in engineering education and careers. Recommendations for policy, leadership, and professional growth are discussed to improve engineering education for female students in Malaysia.

\section{Policy}

The implementation of the TVE system in Malaysia might not be as advanced as other developed countries' systems, but the Malaysian government is actively enhancing the quality of individual systems toward global economy and development. Conversely, TVE policy regarding equity among gender is not formally written by the Malaysian government. Malaysian government should consider a reevaluation of TVE written policy in regards to gender equality. For this reason, this would provide a structure to improve Malaysian support for female students' position in the engineering arena. According to Haddad (1995), "A policy change is normally a 
response to a problem or set of problems in the sector, and must, therefore, start with an appreciation of the educational sector and its context". In contrast, policy is also a paradox, a trouble that is difficult to solve because it can be created as an unintentional caused by people who have a lot of political agendas (Stone, 2002). Yet, Fowler (2009) affirmed that "most education policies are not policy issues at all" because the education policies are more concerned with organizing information than student socialization in education. Also, she claimed that people who have influences in education policies are among those who have close connections within the educational system.

Table 1 shows types of power to influence that education policy. Seven actors are listed, which are the main stakeholders of education settings including governance bodies, school administrators, teachers, support staff, students, parents, and public (Fowler, 2009). The policy actors are required to know their roles and tasks to execute education policy more proficiently. They also should understand and identify types of power and power resources so that they can encounter any problem occurred in the process and solve it according to their level of responsibilities (Fowler, 2009). Friedman (2008) asserted that problem can be a big issue in any organization, and it need to be considered comprehensively to a have better solution. Education policy in Malaysia may not similar with what is illustrated in Figure 1, but it can be an effective model to emulate the process of identifying actor's power in Malaysian TVE. With this approach, the process of evaluating gender policy within TVE will be more successful. The process of policy evaluation has seven main steps; (1) determine the goals of the policy, (2) select indicators, (3) select or develop data-collection instruments, (4) collect data, (5) analyze and summarize data, (6) write evaluation report, and (7) respond to evaluators' recommendations (Fowler, 2009). The policy evaluation is a straightforward process to meet the goal of the current policy.

Table 1. The power of major actors in educational settings (Fowler, 2009)

\begin{tabular}{|c|c|c|}
\hline Actor & Types of Power & Power Resources \\
\hline $\begin{array}{l}\text { Governance bodies (e.g., } \\
\text { legislatures, school boards, } \\
\text { department of education) }\end{array}$ & $\begin{array}{l}\text { Economic dominance } \\
\text { Budget proposal } \\
\text { Budget adoption } \\
\text { Tax policy } \\
\text { Withholding funds } \\
\text { Legal authority } \\
\text { Adoption of laws, rules, policies } \\
\text { Court decisions }\end{array}$ & $\begin{array}{l}\text { Access to money } \\
\text { Control over information } \\
\text { Information } \\
\text { Official positions } \\
\text { Organization }\end{array}$ \\
\hline School administrators & $\begin{array}{l}\text { Economic dominance } \\
\text { Legal authority }\end{array}$ & $\begin{array}{l}\text { Control over careers and working conditions } \\
\text { Control over information } \\
\text { Information } \\
\text { Official positions } \\
\text { Patronage } \\
\text { Visibility }\end{array}$ \\
\hline Teachers & $\begin{array}{l}\text { Economic dominance } \\
\text { Work stoppages } \\
\text { Work slowdowns } \\
\text { Tenure (job protection) } \\
\text { Legal authority } \\
\text { Control over classroom }\end{array}$ & $\begin{array}{l}\text { Control over information about classroom } \\
\text { activities } \\
\text { Numbers } \\
\text { Official positions } \\
\text { Organization }\end{array}$ \\
\hline Support staff & $\begin{array}{l}\text { Economic dominance } \\
\text { Work stoppages } \\
\text { Work slow downs }\end{array}$ & $\begin{array}{l}\text { Numbers } \\
\text { Organization }\end{array}$ \\
\hline Students & $\begin{array}{l}\text { Force } \\
\text { Physical (i.e., threat of disruption, } \\
\text { actual disruption, fights) } \\
\text { Psychic (i.e., heckling, verbal insults) }\end{array}$ & Numbers \\
\hline Parents & Persuasion & $\begin{array}{l}\text { Numbers } \\
\text { Organization }\end{array}$ \\
\hline Public & $\begin{array}{l}\text { Economic dominance } \\
\text { (e.g., voting on funding issues) } \\
\text { Legal authority } \\
\text { (e.g., voting in school elections) }\end{array}$ & $\begin{array}{l}\text { Numbers } \\
\text { Organization }\end{array}$ \\
\hline
\end{tabular}


The ideologies practiced within TVE institutions in Malaysia impact Malaysian female students' opportunities to enroll engineering programs. Stereotypes of women's occupations in Malaysia include domestic jobs, nurses, teacher, and housewife in textbooks and men are perceived to have occupations in line with engineers, politician, and other profound professions (Haque \& Chandran, 2004). Malaysian government should take an initiative to revise and review textbooks which portray hegemony and oppression of Malaysian women related to their career choices. McLaren (2009) refers hegemony as "the maintenance of domination not by the sheer exercise of force but primarily through consensual social practices, social forms, and social structures produced in specific sites such as the church, the state, the school, the mass media, the political system, and the family". Thus, women should be represented as equal character as men in the textbook. The Malaysian education system should consider issues of gender bias and stereotyping of occupational roles because the awareness of bias is the first step to reduce and eliminate the issue of gender bias in Malaysia.

Engineering educators should responsible to review and redesign the existing curriculum to incorporate equality instead of only the male perspectives that the field has been dominated by for years in the Malaysian education system. Engineering programs need to be reformed exclusively to meet the expectations of the students as a whole and requirement of industrial needs. Social, environmental, political, and national economy considerations need to put into account as well as technical aspects towards gender inclusiveness in engineering field (Armstrong \& Leder, 1995).

\section{Leadership}

Teachers are leaders to their students. As leaders, teachers are responsible for their students. Salleh, Sulaiman, and Frederiksen argued being a leader with good vision would make a difference but how they accomplish the vision is another issue. Thus, engineering teachers should possess the qualities of integrity such as being transparent, honest, cooperative, reliable, and purposeful in actions and be good leaders to their follower (Ciulla, 2003). Discussion about gender differences may create arguments and conflicts among students. First and foremost, it is vital for engineering teachers to create a positive classroom atmosphere so that students will feel safe and comfort when gender inequality is discussed in the classroom (Timpson \& Doe, 2008). Along the process, engineering teachers should use the strengths of their emotional intelligence to enhance their leadership style to overcome any difficulties occur because "leaders have always played a primordial emotional role" (Goleman, Boyatzis, \& McKee, 2002).

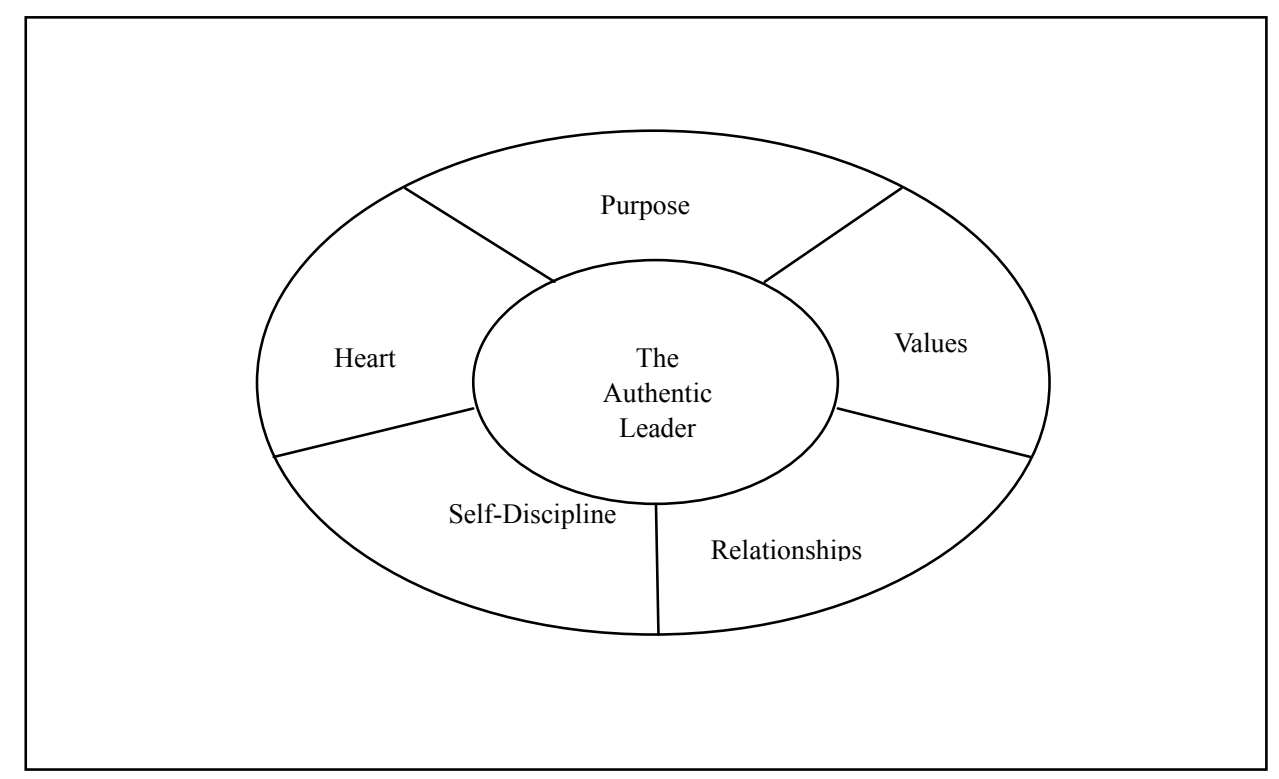

Figure 1. Essentials dimensions of authentic leadership (George, 2003)

Engineering teachers also can choose authentic leadership to make any change and movement in teaching gender to their students. Purpose, values, relationship, self-discipline, and heart are the essential dimensions of authentic leadership that engineering teachers can consider before they execute on what they plan for their teaching (George, 2003). Figure 1 provides an overview of implementing authentic leadership, which can be applied by 
engineering teachers. This model is an ideal method that engineering teachers can continuously enhance their leadership style in teaching. Engineering teachers can go back and forward the process of their roles and responsibilities as it interchange to one and another based on their ability and capability to fulfill the requirements at present time (George, 2003).

Purpose: Engineering teachers need to clear their mind to identify what is the main purpose to incorporate gender into engineering courses. All obstacles and demands along the process can be solved quickly by evaluating based on the main purpose.

Values: All decision making process will be based on the gender values the engineering teachers embed in their teaching.

Relationship: Having good relationship with students, engineering teachers can understand better students' problem.

Self-Discipline: Self-discipline is one of predictor to success. Therefore, engineering teachers need to practice to be sure gender issues can be managed in difficult situations.

Heart: Engineering teachers can be more empathy to other people, considerate, forgive, and pardon others who make negative judgments about their teaching.

It is understood that every teacher has a unique and specific set of traits in their own leadership styles. Nevertheless, this does not mean that they could not connect the dots from the challenges to their power, self interest and influence in educating gender differences to their students.

\section{Professional Growth}

Teachers play an integral part in the change of negative perceptions of female students in education. Male students should be taught gender sensitivity at school and teachers need to allow female students to have an equal chance in the learning process (Hawley, 2007). It is also important to discuss about gender equality to the students because female students can share their perspectives and experiences to promote women's right in the classroom setting (McKeachie \& Svinicki, 2006). Mortenson and Relin (2006) believe people will learn best if they have multiple perspectives about human diversity. Hence, gender equality among male and female students will enhance the education and professional systems of Malaysia.

To help female students to reach their full potential as engineering students, teachers can assign students to compile their own list of engineering definitions, write short synopsis of famous Malaysian female engineers which relate to engineer's work, success and challenge in order to become good engineers (Roman, 2008). This activity would help male students to recognize that Malaysian women are actively participating in supporting Malaysian economy. Engineering teachers in Malaysian TVE institutions can also take an active role to enhance and build positive motivation to female students who are entering engineering fields. Female teachers can be a role model to female students. Teachers also must know how to apply their knowledge and skills on engineering. According to Iskander and Kriftcher (2008), Workshop in Instrumentation, Sensors, and Engineering (WISE) is suitable to be used to teach engineering because it requires teachers to utilize sophisticated and advanced teaching materials and equipment such as instrumentations, prototypes, modules, and machineries.

Not only that, Malaysian teachers should have awareness of the latest advances in technology and engineering. Furthermore, teachers can invite female engineers as guest speakers in the classroom to share their experience, obstacles in their professions and discuss possible solutions with common problems in engineering work environment (Roman, 2008). As a result, teachers can develop and improve their teaching to support today's requirement on engineering. Also, teachers can apply Learning Style Inventory (LSI) by David Kolb to help students to find the best fit learning approach that match with their thinking and attitude about engineering (Holvikivi, 2007). Simultaneously, LSI guide teachers to improve their teaching strategies, suitable with students learning. Teachers also can give female students assignments and projects to explore distinct sciences, technology, and engineering (Roman, 2008). This could give a good start for female students who have difficulties in understanding engineering field in general so they can have clear picture of engineering world and how science, technology and engineering can be differentiate to one and another.

\section{Conclusion}

Women are equally as important as men in making substantive contributions toward sustainable growth and development of a country, including Malaysia. Hence, Malaysian women should be given more opportunities especially in engineering arena to help reduce and eliminate negative perceptions of women's capability in male-dominated professions and environments. Gender inequality at schools and colleges could cause unsatisfied, 
rebellious feelings, and violent environment that may decrease the number of Malaysian women involvement in engineering. Therefore, the discussions of policy, leadership and personal growth contexts are important to find good feasible solutions on the issue of gender bias in Malaysia society. Evaluating the power of major actors in educational settings enables people to indicate their roles and functions according to level of responsibilities can motivates them to act appropriately to reduce inequalities between male and female in engineering fields. Also, integrating authentic leadership which comprise of purpose, values, relationship, self-discipline and heart in teaching may help teachers to make important changes in creating positive environment for female students in classroom. By doing so, it will empower the voice of female students in learning environment. Besides, engineering teachers can improve their teaching strategies by incorporating Learning Style Inventory (LSI) and Workshop in Instrumentation, Sensors, and Engineering (WISE) to teach engineering as it requires teachers to utilize sophisticated and advanced teaching materials and equipment that can accommodate the diverse needs of female students. However, regardless of all the aforementioned suggestions, efforts need to be made in every facet within the Malaysian society from every level and status to encourage greater participation of women in engineering. And, Malaysian women should not let gender issues influence and hinder their ability to engage in male-dominated professions so that it can inspire young female to continue the legacy of women's contribution in engineering.

\section{Acknowledgements}

Thank you and gratitude to Universiti Tun Hussein Onn Malaysia (UTHM) [Vot R041] for the support given in making this study a success.

\section{References}

Ahmad, A. (1998). Women in Malaysia. Country briefing paper. Retrieved from http://www.adb.org/documents/books/country_briefing_papers/women_in_malaysia/women_malaysia.pdf

Anderson, L., \& Gilbride, K. (2007). The future of engineering: A study of the gender bias. McGill Journal of Education, 42(1), 103-117.

Armstrong, J., \& Leder, G. (1995). Engineering education: How to design a gender-inclusive curriculum. Proceeding of the International Congress of Engineering Deans and Industry Leaders, Melbourne, July 1995, (pp. 292-297).

Azman, N., \& Ahmad, A. R. (2006). History, trends, and significant development of adult education in Malaysia. Journal of Historical Studies, 7(2), 66-82.

Ciulla, J. B. (2003). The ethics of leadership. Belmont, CA: Thomson Wadsworth.

Dennis, D. H., \& Hudson, C. C. (2007). Workforce education and two important viewpoints. Journal of Industrial Teacher Education, 44(2), 89-98.

Dewey, J. D., Montrosse, B. E, Schroter, D. C., Sullins, C. D., \& Mattox, J. R. (2008). Evaluator competencies: What's taught versus what's sought. American Journal of Evaluation, 29(3), 268-287. http://dx.doi.org/10. $1177 / 1098214008321152$

Erden, T. F. (2009). A course on gender equity in education: Does it affect gender role attitudes of preservice teachers? Teaching and Teacher Education, 25(3), 409-414. http://dx.doi.org/10.1016/j.tate.2008.11.001

Fowler, F. C. (2009). Policy studies for educational leaders (3rd ed.). Boston, MA: Pearson Education, Inc.

Friedman, T. L. (2008). Hot, flat, and crowded: Why we need a green revolution and how it can renew America. New York, NY: Farrar, Straus, and Giroux.

George, W. W. (2003). Authentic leadership: Rediscovering the secrets to creating lasting values. San Francisco, CA: Jossey-Bass.

Goleman, D., Boyatzis, R., \& McKee, A. (2002). Primal leadership: Realizing the power of emotional intelligence. Boston, MA: Harvard Business School Press.

Haas, A. R. (1999). Trends in articulation arrangements for technical and vocational education in the South East Asian region. Melbourne, Australia: RMIT University. Retrieved from http://www.unevoc.unesco.org/ fileadmin/user_upload/pubs/rmit99.pdf

Haddad, W. D. (1995). Education policy planning process: An applied framework. Fundamental of Educational Planning. Retrieved from http://www.unesco.org/education/pdf/11_200.pdf

Haque, M. S., \& Chandran, S. K. (2004). Discourse of gender: Conflicting ideologies vs. social policies. BRAC 
University Journal, 1(2), 21-32.

Hawley, W. D. (2007). The keys to effective schools (2nd ed.). Thousand Oaks, CA: Corwin Press.

Holvikivi, J. (2007). Learning styles in engineering education: The quest to improve didactic practices. European Journal of Engineering Education, 32(4), 401-408. http://dx.doi.org/10.1080/03043790701332909

Iskander, M., Kapila, V., \& Kriftcher, N. (2008). Workshop in Instrumentation, Sensors, and Engineering (WISE) for Teachers. Innovative Techniques in Instruction Technology, E-learning, E-assessment, and Education, 285-291. http://dx.doi.org/10.1007/978-1-4020-8739-4_50

Ismail, M. (2003). Men and women engineers in a large industrial organization: Interpretation of career progression based on subjective-career experience. Journal of Women in Management Review, 18(1), 60-67. http://dx.doi.org/10.1108/09649420310462334

Jelas, Z. M., \& Dahan, H. M. (2010). Gender and educational performance: The Malaysian perspective. Procedia - Social and Behavioral Sciences, 7, 720-727. http://dx.doi.org/10.1016/j.sbspro.2010.10.098

Kefela, G. T. (2010). Knowledge-based economy and society has become a vital commodity to countries. International NGO Journal, 5(7), 160-166.

Magno, C., \& Silova, I. (2007). Teaching in transition: Examining school-based gender inequities in central/southeastern Europe and the former Soviet Union. International Journal of Educational Development, 27(6), 647-660. http://dx.doi.org/10.1016/j.ijedudev.2006.08.004

Malaysia Government. (2003). The progress of Malaysian women since Independent 1957-2000. Retrieved from http://www.scribd.com/doc/4094821/Progress-of-Malaysian-Women

Malaysia Government. (2006). Ninth Malaysia Plan 2006-2010. Retrieved from http://www.epu.gov.my/rm9/ english/Chapter13.pdf

McKeachie, W. J., \& Svinicki, M. (2006). Teaching tips (12th ed.). Boston, MA: Houghton Mifflin Co.

McLaren, P. (2009). Critical pedagogy: A look at the major concepts. In A. Darder, M. P. Baltodano, \& R. D. Torres (Eds.), The Critical Pedagogy Reader (2nd ed., pp. 61-83). New York, NY: Routledge.

Ministry of Education Malaysia. (2013). Malaysia Education Blueprint 2013 - 2025: Preschool to post-secondary education. Retrieved from http://www.moe.gov.my/cms/upload_files/articlefile/2013/article file_file_003108.pdf

Ministry of Women, Family and Community Development. (2011). Vision, mission and objective. Retrieved from http:/www.kpwkm.gov.my/en/visi-misi-dan-objektif

Mortenson, G., \& Relin, D. O. (2006). Three cups of tea. New York, NY: Penguin Books.

Mustapha, R., \& Abdullah, A. (2001). Globalization and its impact on technical and vocational education and training in Malaysia. Retrieved from http:/www.eric.ed.gov/PDFS/ED466754.pdf

Noor, N. M. (1999). Roles and women's well-being: some preliminary findings from Malaysia. Sex roles, 41(3/4), 123-145. http://dx.doi.org/10.1023/A:1018846010541

O'Gara, L., Mechur, K. M., \& Hughes, K. (2009). Student success courses in the community college: An exploratory study of student perspectives. Community College Review, 36(3), 195-218. http://dx.doi.org/10.1177/0091552108327186

Peramayah, S. (2012). Development of women engineers in Malaysia. Retrieved from http://dspace.unimap.edu. my/dspace/bitstream/123456789/23776/1/dec\%2010.pdf

Rodgers, Y. V. D. M., \& Boyer, T. (2006). Gender and racial differences in vocational education: an international perspective. International Journal of Manpower, 27(4), 308-320. http://dx.doi.org/10.1108/014377206 10679188

Roman, H. T. (2008). Exploring engineering: Pros can help make it real. Tech Directions, 68(4), 16-17.

Salleh, K. M., Sulaiman, N. L., \& Frederiksen, H. (2014). Comparison of teacher licensing between the United States of America and Malaysia: Implementation and practical implication. Education Journal, 3(3), 190-194.

She, H. C. (2000). The interplay of a biology teacher's beliefs, teaching practices and gender biased student-teacher classroom interaction. Educational Research, 42(1), 100-111. http://dx.doi.org/10.1080/00 1318800363953 
Shivy, V. A., \& Sullivan, T. N. (2005). Engineering students' perceptions of engineering specialties. Journal of Vocational Behavior, 67(1), 87-101. http://dx.doi.org/10.1016/j.jvb.2003.05.001

Stone, D. (2002). Policy paradox: The art of political decision making (Rev. ed.). New York, NY: Norton \& Company, Inc.

Subrahmanian, R. (2005). Gender equality in education: Definitions and measurements. International Journal of Educational Development, 25(4), 395-407. http://dx.doi.org/10.1016/j.ijedudev.2005.04.003

Timpson, W. M., \& Doe, S. (2008). Concepts and choices for teaching (2nd ed.). Madison, WI: Atwood Publishing.

UNESCO-UNEVOC. (2010). What is TVET? Retrieved from http://www.unevoc.unesco.org/2.0.html?tx drwiki_pi1[keyword] $=$ What $\% 20$ is $\% 20$ TVET

Velde, C. (2009). Employers' perception of graduate competencies and future trends in higher vocational education in China. Journal of Vocational Education and Training, 61(1), 35-51. http://dx.doi.org/10.1080/13636820902819974

$\mathrm{Wu}, \mathrm{R} . \mathrm{T}$. Y. (2003). A comparative study of the trends in career and technical education among European countries, the United States, and the Republic of China. Journal of Industrial Teacher Education, 40(3), $1-14$.

\section{Copyrights}

Copyright for this article is retained by the author(s), with first publication rights granted to the journal.

This is an open-access article distributed under the terms and conditions of the Creative Commons Attribution license (http://creativecommons.org/licenses/by/3.0/). 